\title{
METHYL BROMIDE BURNS
}

\author{
BY \\ E. C. B. BUTLER, KENNETH M. A. PERRY and J. R. F. WILliAMS \\ From Claybury Emergency Hospital and the Department for Research in Industrial Medicine \\ (Medical Research Council), The London Hospital
}

Methyl bromide $\left(\mathrm{CH}_{3} \mathrm{Br}\right)$ is a colourless, odourless gas at normal temperatures and pressures. It has a boiling point of $4.5^{\circ} \mathrm{C}$., and a melting point of $-93^{\circ} \mathrm{C}$. Its molecular weight is 94.94 and its specific gravity at $0^{\circ} \mathrm{C}$. is 1.732 . At ordinary temperatures, therefore, it is approximately three and a half times as heavy as air. It is a highly stable compound chemically, and while only slightly soluble in water, it is soluble in most organic solvents. Because of its great density it has been extensively used as a fire extinguisher, and in this capacity it is especially valuable in dealing with fires where high octane motor spirit is involved; the methyl bromide forms a cloak around the fire and thus excludes oxygen. An added advantage is that there is no risk of explosion when it is used. During manufacture it is compressed and put into containers as a liquid. When required for use it escapes as a liquid but soon vaporizes if the temperature is above its melting point. Besides its use as a fire extinguisher, it is also used as a refrigerant, as a fumigant, and as an insecticide. In the latter capacity it is valuable for exterminating lice and bed bugs, besides pests which may invade foodstuffs.

Since Jaquet in 1901 drew attention to the poisonous action of methyl bromide by inhalation, there have been many accounts of intoxication by the drug. Very little has, however, been written about the effect of liquid methyl bromide on the skin. Billet and Abel (1940) reported the case of a ' chasseur' who extinguished a fire in an armoured car with a methyl bromide fire extinguisher. $\mathrm{He}$ developed signs of intoxication but also showed a scarlatiniform rash on his arms and stomach, and extensive burns on his feet, which took over four weeks to heal. Watrous (1942) in a study of 90 workers engaged in the filling and sealing rooms of a factory manufacturing methyl bromide, found 22 cases showing skin lesions. Four of these had blisters which healed without dermatitis ; 11 had both blisters and dermatitis, and 7 had dermatitis only. Similar lesions have also been noticed in factories manufacturing methyl bromide in England. Liquid methyl bromide spilt on the skin evaporates very quickly with a cooling but not a freezing sensation like ethyl chloride. Small quantities produce no damage, but repeated application of small amounts or the single application of larger amounts give rise to characteristic changes in the skin. There is first tingling, then a sense of numbness; and finally aching pain. During these stages the skin first appears red and slightly swollen, but after 5-10 hours vesicles or blisters appear, according to the severity of the burn. The vesicles are frequently grouped together, sometimes resembling herpes. The blisters are markedly distended with clear straw-coloured fluid, but do not refill after aspiration. In less severe cases a fine papular or vesicular itching dermatitis may appear after about 7 days, and similar lesions appear as a late complication of healed blisters in severe cases, or at the periphery of the blisters. The dermatitis usually heals within 7 days with conservative treatment: in most cases with considerable desquamation of the skin, similar to that seen after sunburn. The most troublesome feature of the dermatitis is intense itching. Clarke, Roworth and Holling (1945) state that liquid methyl bromide in contact with the skin produces burns, and that it will readily pass through clothing, and even leather boots, but up to the present the French case is the only one of methyl bromide burns to be reported. Ethyl chloride is extensively used in hospitals as an anaesthetic and produces no damage to the skin. Ethyl bromide also appears to be harmless, the only similar organic substance which has a vesicant action is benzyl chloride, which also needs to be handled carefully.

The following incident is therefore of interest. An armoured car was being driven from the north of England to a marshalling park in the south. On the journey a fuse in the electrical apparatus. on the car caused a small fire to break out under the dashboard. Since the armoured car was carrying ammunition the outbreak was dangerous. The vehicle was stopped and the driver got out to direct the traffic. The second driver seized the fire extinguisher which contained $4 \mathrm{lb}$. of methyl bromide, and applied it to the fire which was successfully extinguished. In doing this he squirted some of the methyl bromide on his feet and into the well where the first driver sat. They took little notice of this and drove on for five hours to their destination. They then noticed that their feet were sore, and on removal of their anklets, socks and boots found them red, tender and covered with enormous blisters. A peculiar, musty, pungent smell from their socks was noticed when they arrived in hospital.

\section{Case Reports}

Case 1. H.S., aged 20, was the first driver of the vehicle. His general condition was good. He was apyrexial and the pulse rate was not increased. The dorsum of his right foot was red and swollen, while the dorsum of his left foot was grossly œde- 
matous and covered with large blisters, the largest being 2 in. by 4 in. These blisters were punctured and all dead epithelium removed, and the area was covered with 2 per cent. tannic acid in triple dye solution. Three days later there were no signs of general toxaemia or of local infection, so the foot was again sprayed with triple dye. Nine days after its first application the dye came off spontaneously, and the foot was healed except for a small area which healed in a further five days. He was discharged fit for duty after fourteen days.

Case 2. R.B., aged 23, was the second driver of the vehicle. His general condition was good. $\mathrm{He}$ was apyrexial and his pulse was not raised. Both his feet were red and œdematous, but the burns which did not affect the whole thickness of the skin were more extensive than those in Case 1. This was probably due to the fact that he had more methyl bromide on his boots. The blisters were more extensive on both feet, the largest being 4 in by 5 in. The calves of his legs were also affected. On the right foot the blisters were not punctured, except to obtain fluid for bacteriological examination. It was found to be sterile. The foot was then cleaned with saline and sprayed with sulphathiazole powder containing 5 per cent. light magnesium oxide and calcium penicillin 2,000 units per gram, over which tulle gras was applied. The powder was reapplied three times at 48-hourly intervals; each application resulting in local tingling. At the end of this treatment the foot had healed except for a small raw area near the heel which was slightly infected. Culture from this area was sterile. It was then treated with applications of calamine lotion, but took seven weeks to become covered with epithelium. The left foot was cleaned with saline but the blisters were not touched. The whole area was covered with propamidine isothionate cream (Lannette wax, castor oil and water). This was re-applied every 48 hours for three applications. At the end of this time the whole area was healed except for one small red area. No area was without epithelium. There was no pain throughout treatment. Five weeks after his admission a papular eruption appeared on both legs, but this rapidly subsided on treatment with calamine lotion. He was discharged after eight weeks, fit for duty.

\section{Characters, Prevention and Treatment}

Methyl bromide burns do not extend deeply into the tissues. They are characterized by excessive vesication with reddening and swelling of the surrounding skin, but they rarely extend deep enough to destroy the whole skin. It is apparent that the damage is caused by a chemical and thermal reaction, and is brought out by the methyl bromide being absorbed in the superficial layers of the skin. Any influence retarding evaporation, such as soaked clothing, will favour absorption by prolonging the time of contact. Methyl bromide also dissolves rapidly in rubber and adhesive tape, and Watrous (1942) refers to workers who acquired burns by resting their elbows on sponge rubber pads which could only have been contaminated by occasional drops of liquid methyl bromide. Skin beneath adhesive tape on which methyl bromide has fallen shows severe reactions. Liquid methyl bromide will pass through any type of material. In the case of these two soldiers the burns occurred through army boots and anklets.

Attempts should be made to prevent these burns occurring, and in industry where the substance is manufactured this has been achieved. Notices should be placed on all methyl bromide fire extinguishers warning users of the dangers of the substance, and instructing them that should any of the liquid get on any part of their clothing the garment must be immediately removed and not worn again for at least 48 hours. No attempt should be made to protect the hands of workers with gloves, particularly rubber gloves, and no one should be allowed to handle methyl bromide with surgical dressings on their hands.

The three legs which were burnt and have been described above were treated in three different ways: by propamidine cream, 2 per cent. tannic acid in triple dye solution, and calcium penicillin powder. The leg treated with 2 per cent. tannic acid in triple dye solution cleared first, but it was the one with the least severe burns. All the methods were satisfactory, but the propamidine cream probably brought about the most rapid healing and was painless, whereas calcium penicillin caused considerable tingling after each application.

\section{Summary}

Liquid methyl bromide in contact with the skin causes superficial burns with much vesication. The substance will pass through all articles of clothing.

Warning notices should be fixed on all fire extinguishers containing the substance.

Treatment with 2 per cent. tannic acid in triple dye solution, propamidine cream and calcium penicillin all produce satisfactory healing.

\section{REFERENCES}

Billet and Abel (1940). Gaz. Hôp., 113, 464.

Clarke, C. A., Roworth, C. G., and Holling, H. E. (1945). Brit. J. industr. Med., 2, 17.

Jaquet, A. (1901). Dtsch. Arch. klin. Med., 17, 370

Watrous, R. M. (1942). Industr. Med., 11, 575. 